\title{
For Public Sociology
}

\author{
Von Michael Burawoy*
}

This is how one pictures the angel of history. His face is turned towards the past. Where we perceive a chain of events, he sees one single catastrophe which keeps piling wreckage upon wreckage and hurls it in front of his feet. The angel would like to stay, awaken the dead, and make whole what has been smashed. But a storm is blowing from Paradise; it has got caught in his wings with such violence that the angel can no longer close them. This storm irresistibly propels him into the future to which his back is turned, while the pile of debris before him grows skyward. This storm is what we call progress.

Walter Benjamin, 1940

Walter Benjamin wrote his famous ninth thesis on the philosophy of history as the Nazi army approached his beloved Paris, hallowed sanctuary of civilization's promise. He portrays this promise in the tragic figure of the angel of history, battling in vain against civilization's long march through destruction. To Benjamin, in 1940, the future had never looked bleaker with capitalism-become-fascism in a joint pact with socialism-become-Stalinism to overrun the world. Today, at the dawn of the 21 st century, although communism has dissolved and fascism is a haunting memory, the debris continues to grow skyward. Unfettered capitalism fuels market tyrannies and untold inequities on a global scale, while resurgent democracy too often becomes a thin veil for powerful interests, disenfranchisement, mendacity, and even violence. Once again the angel of history is swept up in a storm, a terrorist storm blowing from Paradise.

In its beginning sociology aspired to be such an angel of history, searching for order in the broken fragments of modernity, seeking to salvage the promise of progress. Thus, Karl Marx recovered socialism from alienation; Emile Durkheim redeemed organic solidarity from anomie and egoism. Max Weber, despite premonitions of »a polar night of icy darkness, « could discover freedom in rationalization, and extract meaning from disenchantment. On this side of the Atlantic W. E. B. Du Bois pioneered pan-Africanism in reaction to racism and imperialism, while Jane Addams tried to snatch peace and internationalism from the jaws of war. But then the storm of progress got caught in sociology's wings. If our predecessors set out to change the world we have too often ended up conserving it. Fighting for a place in the academic sun, sociology developed its own specialized knowledge, whether in the form of the brilliant and lucid erudition of Robert Merton (1949), the arcane and grand design of Talcott Parsons $(1937,1951)$, or the early statistical treatment of mobility and stratification, culminating in the work of Peter Blau and Otis Dudley Duncan (1967). Reviewing the 1950s, Seymour Martin Lipset and Neil Smelser (1961: 1-8) could triumphantly declare sociology's moral prehistory finally over and the path to science fully open. Not for the first time Comtean visions had gripped sociology's professional elite. As before this burst of »pure science« was short lived. A few years later, campuses - especially those where sociology was

*) Innumerable people, impossible to acknowledge by name, have contributed to this project. However, the author would like to thank Sally Hillsman, Bobbie Spalter-Roth and Carla Howery in the American Sociological Association office, all of whom helped in many ways, not least in providing facts and figures, and organizing speaking engagements. For their comments on a draft of this paper thanks to Barbara Risman, Don Tomaskovic-Devey, and their students, as well as to Chas Camic and Jerry Jacobs. The live version of this address can be obtained on DVD from the American Sociological Association. Reprint from the »American Sociological Review« (2005, Vd. 70, pp 4-28).

Soziale Welt 56 (2005), S. 347 - 374 
strong - were ignited by political protest for free speech, civil rights, and peace, indicting consensus sociology and its uncritical embrace of science. The angel of history had once again fluttered in the storm.

The dialectic of progress governs our individual careers as well as our collective discipline. The original passion for social justice, economic equality, human rights, sustainable environment, political freedom or simply a better world, that drew so many of us to sociology, is channeled into the pursuit of academic credentials. Progress becomes a battery of disciplinary techniques - standardized courses, validated reading lists, bureaucratic rankings, intensive examinations, literature reviews, tailored dissertations, refereed publications, the all-mighty $\mathrm{CV}$, the job search, the tenure file, and then policing one's colleagues and successors to make sure we all march in step. Still, despite the normalizing pressures of careers, the originating moral impetus is rarely vanquished, the sociological spirit cannot be extinguished so easily.

Constrictions notwithstanding, discipline - in both the individual and collective senses of the word - has born its fruits. We have spent a century building professional knowledge, translating common sense into science, so that now, we are more than ready to embark on a systematic back-translation, taking knowledge back to those from whom it came, making public issues out of private troubles, and thus regenerating sociology's moral fiber. Herein lies the promise and challenge of public sociology, the complement and not the negation of professional sociology.

To understand the production of public sociology, its possibilities and its dangers, its potentialities and its contradictions, its successes and failures, during the last 18 months I have discussed and debated public sociology in over 40 venues, from community colleges to state associations to elite departments across the United States - as well as in England, Canada, Norway, Taiwan, Lebanon, and South Africa. The call for public sociology resonated with audiences wherever I went. Debates resulted in a series of symposia on public sociology, including ones in Social Problems (February, 2004), Social Forces (June, 2004), and Critical Sociology (Summer, 2005). Footnotes, the newsletter of the American Sociological Association (ASA), developed a special column on public sociology, the results of which are brought together in An Invitation to Public Sociology (American Sociological Association 2004). Departments have organized awards and blogs on public sociology, the ASA has unveiled its own site for public sociology, and introductory textbooks have taken up the theme of public sociology. Sociologists have appeared more regularly in the opinion pages of our national newspapers. The 2004 ASA annual meetings, devoted to the theme of public sociologies, broke all records for attendance and participation and did so by a considerable margin. These dark times have aroused the angel of history from his slumbers.

I offer 11 theses. They begin with the reasons for the appeal of public sociologies today, turning to their multiplicity and their relation to the discipline as a whole - the discipline being understood both as a division of labor and as a field of power. I examine the matrix of professional, policy, public, and critical sociologies as it varies historically and among countries, comparing sociology with other disciplines, before finally turning to what makes sociology so special, not just as a science but as a moral and political force.

\section{Thesis I: The Scissors Movement}

The aspiration for public sociology is stronger and its realization ever more difficult, as sociology has moved left and the world has moved right.

To what shall we attribute the current appeal of public sociology? To be sure, it reminds so many of why they became sociologists, but public sociology has been around for some time, so why might it suddenly take off? 
Over the last half century the political center of gravity of sociology has moved in a critical direction while the world it studies has moved in the opposite direction. Thus, in 1968, members of the ASA were asked to vote on a member resolution against the Vietnam War. Of those who voted, two-thirds opposed the ASA taking a position, while in a separate opinion question, 54\% expressed their individual opposition to the war (Rhoades 1981:60) roughly the same proportion as in the general population at the time. In 2003, 35 years later, a similar member resolution against the war in Iraq was put to the ASA membership and two-thirds favored the resolution (Footnotes July-August 2003). Even more significant, in the corresponding opinion poll, $75 \%$ of those who voted said they were against the war, at a time (late May, 2003) that $75 \%$ of the general population supported the war. ${ }^{1}$

Given the leftward drift of the 1960s this is an unexpected finding. Despite the turbulence of the 1968 Annual Meeting in Boston, which included Martin Nicolaus's famous and fearless attack on »fat-cat sociology, « and forthright demands from the Caucus of Black Sociologists, the Radical Caucus, and the Caucus of Women Sociologists, oppositional voices were still in a minority. The majority of members had grown up in and imbibed the liberal conservatism of the earlier postwar sociology. Over time, however, the radicalism of the 1960s diffused through the profession, albeit in diluted form. The increasing presence and participation of women and racial minorities, the ascent of the 1960s generation to leadership positions in departments and our association, marked a critical drift that is echoed in the content of sociology. ${ }^{2}$

Thus, political sociology turned from the virtues of American electoral democracy to studying the state and its relation to classes, social movements as political process, and the deepening of democratic participation. Sociology of work turned from processes of adaptation to the study of domination and labor movements. Stratification shifted from the study of social mobility within a hierarchy of occupational prestige to the examination of changing structures of social and economic inequality - class, race, and gender. The sociology of development abandoned modernization theory for underdevelopment theory, world systems' analyses, and state orchestrated growth. Race theory moved from theories of assimilation to political economy to the study of racial formations. Social theory introduced more radical interpretations of Weber and Durkheim, and incorporated Marx into the canon. If feminism was not quite let into the canon, it certainly had a dramatic impact on most substantive fields of sociology. Globalization is wreaking havoc with sociology's basic unit of analysis - the nation-state - while compelling deparochialization of our discipline. There have, of course, been counter-movements - for example, the ascendancy of assimilation studies in immigration or the neoinstitutionalists who document the worldwide diffusion of American institutions - but over the last half century the overwhelming movement has been in a critical direction.

If the succession of political generations and the changing content of sociology is one arm of the scissors, the other arm, moving in the opposite direction, is the world we study. Even as the rhetoric of equality and freedom intensifies so sociologists have documented ever-deepening inequality and domination. Over the last 25 years earlier gains in economic security and civil rights have been reversed by market expansion (with their attendant inequalities) and coercive states, violating rights at home and abroad. All too often, market and state have

1) Data for public support of the Vietnam War come from Mueller (1973: Table 3.3), while data for public support of Iraq War come from Gallup Polls.

2) In 1968, the 19 elected members of the ASA Council were white and male, except for one woman, Mirra Komarovsky. In 2004, the 20 member Council was exactly 50\% female and 50\% minority. As to the broad profession, between 1966 and $1969,18.6 \%$ of sociology $\mathrm{PhDs}$ were earned by women, whereas the figure was $58.4 \%$ in 2001. Figures for racial breakdown begin later. In 1980, $14.4 \%$ of sociology PhDs were earned by minorities, whereas in 2001 the figure was $25.6 \%$. 
collaborated against humanity in what has commonly come to be known as neoliberalism. To be sure, sociologists have become more sensitive, more focused on the negative, but the evidence they have accumulated does suggest regression in so many arenas. And, of course, as I write, we are governed by a regime that is deeply antisociological in its ethos, hostile to the very idea of »society«.

In our own backyard, the university has suffered mounting attacks from the National Association of Scholars for harboring too many liberals. At the same time, facing declining budgets, and under intensified competition, public universities have responded with market solutions - joint ventures with private corporations, advertising campaigns to attract students, fawning over private donors, commodifying education through distance learning, employing cheap temporary professional labor, not to mention the armies of low-paid service workers (Kirp 2003; Bok 2003). Is the market solution the only solution? Do we have to abandon the very idea of the university as a »publicå good? The interest in a public sociology is, in part, a reaction and a response to the privatization of everything. Its vitality depends on the resuscitation of the very idea of $»$ public, « another casualty of the storm of progress. Hence the paradox: the widening gap between the sociological ethos and the world we study inspires the demand and, simultaneously, creates the obstacles to public sociology. How should we proceed?

\section{Thesis II: The Multiplicity of Public Sociologies}

There are multiple public sociologies, reflecting different types of publics and multiple ways of accessing them. Traditional and organic public sociologies are two polar but complementary types. Publics can be destroyed but they can also be created. Some never disappear - our students are our first and captive public.

What should we mean by public sociology? Public sociology brings sociology into a conversation with publics, understood as people who are themselves involved in conversation. It entails, therefore, a double conversation. Obvious candidates are W. E. B. Du Bois (1903), The Souls of Black Folk, Gunnar Myrdal (1994), An American Dilemma, David Riesman (1950), The Lonely Crowd, and Robert Bellah et al. (1985), Habits of the Heart. What do all these books have in common? They are written by sociologists, they are read beyond the academy, and they become the vehicle of a public discussion about the nature of U.S. society - the nature of its values, the gap between its promise and its reality, its malaise, its tendencies. In the same genre of what I call traditional public sociology we can locate sociologists who write in the opinion pages of our national newspapers where they comment on matters of public importance. Alternatively, journalists may carry academic research into the public realm, as they did with, for example, Chris Uggen and Jeff Manza's (2002) article in the American Sociological Review on the political significance of felon disenfranchisement and Devah Pager's (2002) dissertation on the way race swamps the effects of criminal record on the employment prospects of youth. With traditional public sociology the publics being addressed are generally invisible in that they cannot be seen, thin in that they do not generate much internal interaction, passive in that they do not constitute a movement or organization, and they are usually mainstream. The traditional public sociologist instigates debates within or between publics, although he or she might not actually participate in them.

There is, however, another type of public sociology - organic public sociology in which the sociologist works in close connection with a visible, thick, active, local and often counter-public. The bulk of public sociology is indeed of an organic kind - sociologists working with a labor movement, neighborhood associations, communities of faith, immigrant rights groups, human rights organizations. Between the organic public sociologist and a public is a 
dialogue, a process of mutual education. The recognition of public sociology must extend to the organic kind which often remains invisible, private, and is often considered to be apart from our professional lives. The project of such public sociologies is to make visible the invisible, to make the private public, to validate these organic connections as part of our sociological life.

Traditional and organic public sociologies are not antithetical but complementary. Each informs the other. The broadest debates in society, for example about family values, can inform and be informed by our work with welfare clients. Debates about NAFTA can shape the sociologist's collaboration with a trade union local; working with prisoners to defend their rights can draw on public debates about the carceral complex. Berkeley graduate students, Gretchen Purser, Amy Schalet, and Ofer Sharone (2004), studied the plight of lowpaid service workers on campus, bringing them out of the shadows, and constituting them as a public to which the university should be accountable. The report drew on wider debates about the working poor, immigrant workers and the privatization and corporatization of the university, while feeding public discussion about the academy as a principled community. In the best circumstances traditional public sociology frames organic public sociology, while the latter disciplines, grounds, and directs the former.

We can distinguish between different types of public sociologist and speak of different publics but how are the two sides - the academic and the extra-academic - brought into dialogue? Why should anyone listen to us rather than the other messages streaming through the media? Are we too critical to capture the attention of our publics? Alan Wolfe (1989), Robert Putnam (2001), and Theda Skocpol (2003), go further and warn that publics are disappearing - destroyed by the market, colonized by the media or stymied by bureaucracy. The very existence of a vast swath of public sociology, however, does suggest there is no shortage of publics if we but care to seek them out. But we do have a lot to learn about engaging them. We are still at a primitive stage in our project. We should not think of publics as fixed but in flux and that we can participate in their creation as well as their transformation. Indeed, part of our business as sociologists is to define human categories - people with AIDS, women with breast cancer, women, gays - and if we do so with their collaboration we create publics. The category woman became the basis of a public - an active, thick, visible, national nay international counter-public - because intellectuals, sociologists among them, defined women as marginalized, left out, oppressed, and silenced, that is, defined them in ways they recognized. From this brief excursion through the variety of publics it is clear that public sociology needs to develop a sociology of publics - working through and beyond a lineage that would include Robert Park (1972[1904]), Walter Lippmann (1922), John Dewey (1927), Hanna Arendt (1958), Jürgen Habermas (1991 [1962]), Richard Sennett (1977), Nancy Fraser (1997), and Michael Warner (2002) - to better appreciate the possibilities and pitfalls of public sociology.

Beyond creating other publics we can constitute ourselves as a public that acts in the political arena. As Durkheim famously insisted professional associations should be an integral element of national political life - and not just to defend their own narrow professional interests. So the American Sociological Association has much to contribute to public debate as indeed it has, when it submitted an Amicus Curiae brief to the Supreme Court in the Michigan Affirmative Action case, when it declared that sociological research demonstrated the existence of racism and that racism has both social causes and consequences, when its members adopted resolutions against the War in Iraq and against a constitutional amendment that would outlaw same-sex marriage, or when the ASA Council protested the imprisonment of the Egyptian sociologist, Saad Ibrahim. Speaking on behalf of all sociologists is difficult and dangerous. We should be sure to arrive at public positions through open dialogue, through free and equal participation of our membership, through deepening our internal democracy. The multiplicity of public sociologies reflects not only different publics but different value 
commitments on the part of sociologists. Public sociology has no intrinsic normative valence, other than the commitment to dialogue around issues raised in and by sociology. It can as well support Christian Fundamentalism as it can Liberation Sociology or Communitarianism. If sociology actually supports more liberal or critical public sociologies that is a consequence of the evolving ethos of the sociological community.

There is one public that will not disappear before we do - our students. Every year we create approximately 25,000 new BAs, who have majored in sociology. What does it mean to think of them as a potential public? It surely does not mean we should treat them as empty vessels into which we pour our mature wine, nor blank slates upon which we inscribe our profound knowledge. Rather we must think of them as carriers of a rich lived experience that we elaborate into a deeper self-understanding of the historical and social contexts that have made them who they are. With the aid of our grand traditions of sociology, we turn their private troubles into public issues. We do this by engaging their lives not suspending them; starting from where they are, not from where we are. Education becomes a series of dialogues on the terrain of sociology that we foster - a dialogue between ourselves and students, between students and their own experiences, among students themselves, and finally a dialogue of students with publics beyond the university. Service learning is the prototype: as they learn students become ambassadors of sociology to the wider world just as they bring back to the classroom their engagement with diverse publics. ${ }^{3}$ As teachers we are all potentially public sociologists.

It is one thing to validate and legitimate public sociology by recognizing its existence, bringing it out from the private sphere into the open where it can be examined and dissected, it is another thing to make it an integral part of our discipline, which brings me to Thesis III.

\section{Thesis III: The Division of Sociological Labor}

\section{Public sociology is part of a broader division of sociological labor that also includes policy sociology, professional sociology and critical sociology.}

Champion of traditional public sociology, C. Wright Mills (1959), and many others since him, would turn all sociology into public sociology. Mills harks back to the late 19th century forefathers, for whom scholarly and moral enterprises were indistinguishable. There is no turning back, however, to that earlier period before the academic revolution. Instead we have to move forward and work from where we really are, from the division of sociological labor.

The first step is to distinguish public sociology from policy sociology. Policy sociology is sociology in the service of a goal defined by a client. Policy sociology's raison d'etre is to provide solutions to problems that are presented to us, or to legitimate solutions that have already been reached. Some clients specify the task of the sociologist with a narrow contract whereas other clients are more like patrons defining broad policy agendas. Being an expert witness, for example, an important service to the community, is a relatively well-defined relation with a client whereas funding from the State Department to investigate the causes of terrorism or poverty might offer a much more open research agenda.

Public sociology, by contrast, strikes up a dialogic relation between sociologist and public in which the agenda of each is brought to the table, in which each adjusts to the other. In public sociology, discussion often involves values or goals that are not automatically shared by

3) There is a vast literature on service learning. Two volumes of special relevance to sociology are Ostrow et al. (1999) and Marullo and Edwards (2000). 
both sides so that reciprocity, or as Habermas (1984) calls it »communicative action, « is often hard to sustain. Still, it is the goal of public sociology to develop such a conversation.

Barbara Ehrenreich's (2002) best-selling Nickel and Dimed - an ethnography of low-wage work that indicted, among others, Wal-Mart's employment practices is an example of public sociology, whereas William Bielby's (2003) expert testimony in the sexual discrimination suite against the same company would be a case of policy sociology. The approaches of public and policy sociology are neither mutually exclusive nor even antagonistic. As in this case they are often complementary. Policy sociology can turn into public sociology, especially when the policy fails as in the case of James Coleman's $(1966,1975)$ busing proposals or when the government refuses to support policy proposals such as William Julius Wilson's (1996) recommendation to create jobs in order to alleviate racialized poverty, or Paul Starr's involvement in abortive healthcare reforms of the Clinton administration. Equally, public sociology can often turn into policy sociology. Diane Vaughan's (2004) widely reported engagement with the media over the Columbia Shuttle disaster, based on her earlier research into the Challenger disaster, paved the way for her ideas to be taken up in the report of the Columbia Accident Investigation Board (2003) and, in particular, its indictment of the organizational culture of the National Aeronautical and Space Administration (NASA).

There can be neither policy nor public sociology without a professional sociology that supplies true and tested methods, accumulated bodies of knowledge, orienting questions, and conceptual frameworks. Professional sociology is not the enemy of policy and public sociology but the sine qua non of their existence - providing both legitimacy and expertise for policy and public sociology. Professional sociology consists first and foremost of multiple intersecting research programs, each with their assumptions, exemplars, defining questions, conceptual apparatuses, and evolving theories. ${ }^{4}$ Most subfields contain well established research programs, such as organization theory, stratification, political sociology, sociology of culture, sociology of the family, race, economic sociology, etc. There are often research programs within subfields, such as organizational ecology within organization theory. Research programs advance by tackling their defining puzzles that come either from external anomalies (inconsistencies between predictions and empirical findings) or from internal contradictions. Thus, the research program on social movements was established by displacing the »irrationalist « and psychological theories of collective behavior, and building a new framework around the idea of resource mobilization which in turn led to the formulation of a political process model, framing and most recently the attempt to incorporate emotions. Within each research program, exemplary studies solve one set of puzzles and at the same time create new ones, turning the research program in new directions. Research programs degenerate as they become swamped by anomalies and contradictions, or when attempts to absorb puzzles become more a face saving device than a genuine theoretical innovation. Goodwin and Jasper (2004, chap. 1) argue that such has been the fate of the social movement theory as it has become overly general and ingrown.

It is the role of critical sociology, my fourth type of sociology, to examine the foundations both the explicit and the implicit, both normative and descriptive - of the research programs of professional sociology. We think here of the work of Robert Lynd (1939) who complained that social science was abdicating its responsibility to confront the pressing cultural and institutional problems of the time by obsessing about technique and specialization. C. Wright Mills (1959) indicted professional sociology of the 1950s for its irrelevance, veering toward abstruse »grand theory« or meaningless »abstracted empiricism« that divorced data from context. Al-

4) In the formulation of the idea of research programs I have been very influenced by Imre Lakatos (1978) and his debates with Thomas Kuhn, Karl Popper, and others. 
vin Gouldner (1970) took structural functionalism to task for its domain assumptions about a consensus society that were out of tune with the escalating conflicts of the 1960s. Feminism, queer theory and critical race theory have hauled professional sociology over the coals for overlooking the ubiquity and profundity of gender, sexual, and racial oppressions. In each case critical sociology attempts to make professional sociology aware of its biases, silences, promoting new research programs built on alternative foundations. Critical sociology is the conscience of professional sociology just as public sociology is the conscience of policy sociology.

Critical sociology also gives us the two questions that place our four sociologies in relation to each other. The first question is one posed by Alfred McLung Lee (1976) in his Presidential Address, »Sociology for Whom?« Are we just talking to ourselves (an academic audience) or are we also addressing others (an extra-academic audience). To pose this question is to answer it, since few would argue for a hermetically sealed discipline, or defend pursuing knowledge simply for knowledge's sake. To defend engaging extra-academic audiences, whether serving clients or talking to publics, is not to deny the dangers and risks that go with it, but to say that it is necessary despite or even because of those dangers and risks.

The second question is Lynd's question: »Sociology for What? « Should we be concerned with the ends of society or only with the means to reach those ends. This is the distinction underlying Max Weber's discussion of technical and value rationality. Weber, and following him the Frankfurt School were concerned that technical rationality was supplanting value discussion, what Horkheimer (1974[1947]) referred to as the eclipse of reason or what he and his collaborator Theodor Adorno (1969[1944]) called the dialectic of enlightenment. I call the one type of knowledge instrumental knowledge, whether it be the puzzle solving of professional sociology or the problem solving of policy sociology. I call the other reflexive knowledge because it is concerned with a dialogue about ends, whether the dialogue takes place within the academic community about the foundations of its research programs or between academics and various publics about the direction of society. Reflexive knowledge interrogates the value premises of society as well as our profession. The overall scheme is summarized in Table 1.5

\section{Table 1. Division of Sociological Labor}

\begin{tabular}{lcc}
\hline \hline & Academic Audience & Extra-academic Audience \\
\hline Instrumental Knowledge & Professional & Policy \\
Reflexive Knowledge & Critical & Public \\
\hline
\end{tabular}

In practice, any given piece of sociology can straddle these ideal types or move across them over time. For example, already I have noted that the distinction between public and policy sociology can often blur - sociology can simultaneously serve a client and generate public debate.

5) This scheme bears an uncanny resemblance to Talcott Parsons's (1961) famous four functions - adaptation, goal attainment, integration, and latency (pattern maintenance) (AGIL) - that any system has to fulfill to survive. If critical sociology corresponds to the latency function based on value commitments, and public sociology corresponds to integration, where influence is the medium of exchange, then policy sociology corresponds to goal attainment, and professional sociology with its economy of credentials corresponds to adaptation. Habermas (1984, chap. 7) gives Parsons a critical twist by referring to the colonization of the life-world (latency and integration) by the system (adaptation and goal attainment). As we shall see Thesis VII combines Habermas's colonization thesis with Bourdieu's (1988 [1984]) field analysis of the academic world. 
Categories are social products. This categorization of sociological labor, redefines the way we regard ourselves. I'm engaging in what Pierre Bourdieu (1986[1979], 1988[1984]) would call a classification struggle, displacing debates about quantitative and qualitative techniques, positivist and interpretive methodologies, micro and macro sociology by centering two questions: for whom and for what do we pursue sociology? The remaining theses attempt to justify and expand this classification system.

\section{Thesis IV: The Elaboration of Internal Complexity}

The questions - »knowledge for whom? « and »knowledge for what? «-define the fundamental character of our discipline. They not only divide sociology into four different types, but allow us to understand how each type is internally constructed.

Our four types of knowledge represent not only a functional differentiation of sociology but also four distinct perspectives on sociology. The division of sociological labor looks very different from the standpoint of critical sociology as compared, for example, with the view from policy sociology! Indeed, critical sociology largely defines itself by its opposition to professional (»mainstream«) sociology, itself viewed as inseparable from renegade policy sociology. Policy sociology pays back in kind, attacking critical sociology for politicizing and thereby discrediting the discipline. Thus, from within each category we tend to essentialize, homogenize and stereotype the others. We must endeavor, therefore, to recognize the complexity of all four types of sociology. We can best do this by once again posing our two basic questions: knowledge for whom and knowledge for what? This results in an internal differentiation of each type of sociology, and, therefore, a more nuanced picture. We also learn about the tensions within each type driving it in this direction or that.

Let us begin with professional sociology. At its core is the creation, elaboration, degeneration of multiple research programs. But there is also a policy dimension of professional sociology that defends sociological research in the wider world - defense of funds for politically contested research, such as the study of sexual behavior; the determination of human subjects protocols; the pursuit of government support, say, for minority fellowship programs, etc. This policy dimension of professional sociology is concentrated in the office of the American Sociological Association, and represented in the pages of its newsletter Footnotes. Then there is the public face of professional sociology, presenting research findings in an accessible manner for a lay audience. This was the avowed purpose of the new magazine, Contexts, but a similar function is performed by the regular Congressional Briefings organized by the ASA office. Here, also, we find the plethora of teachers who disseminate the findings of sociological research and, of course, the writing of textbooks. It is a delicate line that separates this public face of professional sociology from public sociology itself, but the former is more intimately concerned with securing the conditions for our core professional activities.

Finally, there is the critical face of professional sociology - debates within and between research programs such as those over the relative importance of class and race, over the effects of globalization, over patterns of overwork, over the class bases of electoral politics, over the sources of underdevelopment, and so forth. Such critical debates are the subject of the articles in The Annual Review of Sociology, and they inject the necessary dynamism into our research programs. The four divisions of professional sociology are represented in Table 2. 
Table 2. Dissecting Professional Sociology

\begin{tabular}{ll}
\hline \hline $\begin{array}{l}\text { Professional } \\
\begin{array}{l}\text { Research conducted within research programs } \\
\text { that define assumptions, theories, concepts, } \\
\text { questions, and puzzles. }\end{array}\end{array}$ & $\begin{array}{r}\text { Policy } \\
\text { Defense of sociological research, human subjects, fun- } \\
\text { ding, congressional briefings }\end{array}$ \\
$\begin{array}{ll}\text { Critical } \\
\begin{array}{l}\text { Critical debates of the discipline within and } \\
\text { between research programs }\end{array}\end{array}$ & $\begin{array}{c}\text { Public } \\
\text { Concern for the public image of sociology, presenting } \\
\text { findings in an accessible manner, teaching basics of } \\
\text { sociology and writing text books }\end{array}$ \\
\hline
\end{tabular}

Because of its size, we can discern a functional differentiation, or as Abbott (2001) might call it »fractalization, « of professional sociology, but the other types of sociology are less internally developed so that it is better to talk of their different aspects or dimensions. Thus, the core activity of public sociology - the dialogue between sociologists and their publics is supported (or not) by professional, critical and policy moments. Take, for example, Boston College's Media Research and Action Project that brings sociologists together with community organizers to discover how best to present social issues to the media. There is a professional moment to this project based on William Gamson's idea of framing, a critical moment based on the limited ways in which the media operate, and a policy moment that grapples with the concrete aims of community organizers. Charlotte Ryan (2004) describes the tensions within the project that stem from the contradictory demands between the immediacy of public sociology and the career rhythms of professional sociology, while Gamson (2004) underlines the university's limited economic commitment to a project to empower local communities.

Policy sociology also has its professional, critical and public moments. Here an interesting case is Judy Stacey's (2004) experience as an expert witness defending same-sex marriage in Ontario Canada. The legal opponents of same-sex marriage drew on her widely read article published in the American Sociological Review (Stacey and Biblarz 2001). The authors argued that while studies show some slight differences in the effects of gay parenting on children - that they were more open to sexual diversity - there was no evidence that the effects were in any way »harmful. « Opponents of same-sex marriage argued that Stacey and Biblarz had drawn on studies so scientifically weak that no such conclusions could be drawn. Judy Stacey, therefore, found herself in the unaccustomed position of defending the scientific rigor of her conclusions. Moreover, her defense of gay civil liberties entailed the defense of marriage - an institution she had subjected to intense criticism in her scholarly writings. In this case, we see how constraining policy sociology can be and how its dependence upon professional sociology can pit it against critical and public sociologies. The four faces of any given type of sociology may not be in harmony with each other.

We can see this again in critical sociology. In her classic article, »A Sociology for Women, « Dorothy Smith (1987, chap. 2) took sociology to task for its universalization of the male standpoint, especially the standpoint of ruling men who command the macro-structures of society. Drawing on the canonical writings of Alfred Schutz, she elaborates the standpoint of women as rooted in the micro-structures of everyday life - the invisible labor that supports the macro structures. Patricia Hill Collins (1991) further developed standpoint analysis by insisting that insight into society comes from those who are multiply oppressed - poor black women - but she too drew on conventional social theory, in her case not Schutz but George Simmel and Robert Merton, to elaborate the critique of professional sociology. Moreover, for her there was a public moment too - the connection of black female intellectuals to the culture of poor black women was necessary to bring greater universality to professio- 
nal sociology. Thus, we see the professional and public moments of critical sociology but what of its policy moment? Could one argue that here lies the realpolitik of defending spaces for critical thought within the university, spaces that would include interdisciplinary programs, institutes, and the struggle for representation?

These are just a few examples to illustrate the complexity of each type of sociology, recognizing their academic and an extra-academic as well as their instrumental and reflexive dimensions. We should not forget this complex internal composition as we refocus on the relations among the four major types.

\section{Thesis V: Locating the Sociologist}

A distinction must be made between sociology and its internal divisions on the one side and sociologists and their trajectories on the other. The life of the sociologist is propelled by the mismatch of her or his sociological habitus and the structure of the disciplinary field as a whole.

We should distinguish between the division of sociological labor and the sociologists who inhabit one or more places within it. About $30 \%$ of $\mathrm{PhDs}$ are employed outside the university, primarily in the world of policy research from where they may venture into the public realm (Kang 2003). The 70\% of PhDs, who teach in universities, occupy the professional quadrant, conducting research or disseminating its results, but they may hold positions in other quadrants too, at least if they have tenure track positions. By contrast, the army of contingent workers - adjuncts, temporary lecturers, part time instructors - are stuck in a single place, paid a pittance $(\$ 2,000$ to $\$ 4,000$ a course) for their often dedicated teaching, with insecure employment and usually without benefits (Spalter-Roth and Erskine 2004). They are more prevalent in the high prestige universities where they can amount to $40 \%$ of employees teaching up to $40 \%$ of courses. These are the underlaborers who subsidize the research and the salaries of the permanent faculty, releasing them for other activities.

Thus, many of our most distinguished sociologists have occupied multiple locations. James Coleman, for example, simultaneously worked in both professional and policy worlds while being hostile to critical and public sociologies. Christopher Jencks, who has worked in similar policy fields, is unusual in combining critical and public moments with professional and policy commitments. Arlie Hochschild's sociology of emotions is strung out between professional and critical sociology whereas her research on work and family combines public and policy sociology. Of course, these sociologists have or had comfortable positions in top ranked sociology departments where conditions of work permit multiple-locations. Most of us only occupy one quadrant at a time. So we should also focus on careers.

Sociologists are not only simultaneously located in different positions, but assume trajectories through time among our four types of sociology. Before the consolidation of professional careers, movement among the quadrants was more erratic. Increasingly disaffected with the academy and marginalized within it by his race, after completing The Philadelphia Negro in 1899, and after setting up and running the Atlanta Sociological Laboratory at the University of Atlanta between 1897 and 1910, W. E. B. Du Bois left academia to found the National Association for the Advancement of Colored People (NAACP) and became editor of its magazine, Crisis. In this public role he wrote all sorts of popular essays, inevitably influenced by his sociology. In 1934 he returned to the academy to chair the sociology department at Atlanta, where he finished another classic monograph, Black Reconstruction, only to depart once again, after World War Two, for national and international public venues. His relentless campaigns for racial justice were the acme of public sociology, although, of 
course, his ultimate aim was always to change policy. Public sociology is often an avenue for the marginalized, locked out of the policy arena and ostracized in the academy.

While W. E. B. Du Bois was taking the route out of the academy, his nemesis, another major figure in the sociology of race, Robert Park, was traveling in the opposite direction. ${ }^{6}$ After years as a journalist, which included radical exposés of Belgium's atrocities in the Congo, he became Booker T. Washington's private secretary and research analyst, before entering, and then shaping and professionalizing the department of sociology at the University of Chicago (Lyman 1992).

C. Wright Mills was of a later generation, but like Du Bois he became increasingly disaffected with the academy. After completing his undergraduate degree in philosophy at the University of Texas he went to Wisconsin to work with the German émigré Hans Gerth. There he wrote his dissertation on pragmatism. Robert Merton and Paul Lazarsfeld recruited him to Columbia University because he showed such promise as a professional sociologist. Unable to tolerate the »illiberal practicality « of Lazarsfeld's Bureau of Applied Research he turned from instrumental sociology to a public sociology - New Men of Power, White Collar and Power Elite. At the end of his short life he would return to the promise and betrayal of sociology in his inspirational The Sociological Imagination. This turn to critical sociology coincided with a move beyond sociology into the realm of the public intellectual with Listen, Yankee! and The Causes of World War Three - books that were only distantly connected to sociology. ${ }^{7}$

Today careers in sociology are more heavily regimented than they were in Mills's time. A typical graduate student, perhaps inspired by an undergraduate teacher or burnt out from a draining social movement - enters graduate school with a critical disposition, wanting to learn more about the possibilities of social change, whether this be limiting the spread of AIDS in Africa, the deflection of youth violence, the conditions of success of feminist movements in Turkey and Iran, family as a source of morality, variation in support for capital punishment, public misconstrual of Islam, etc. There she confronts a succession of required courses, each with its own abstruse texts to be mastered or abstract techniques to be acquired. After three or four years she is ready to take the qualifying or preliminary examinations in three or four areas, whereupon she embarks on her dissertation. The whole process can take anything from 5 years up. It is as if graduate school is organized to winnow away at the moral commitments that inspired the interest in sociology in the first place.

Just as Durkheim stressed the non-contractual elements of contract - the underlying consensus and trust without which contracts would be impossible - so equally we must appreciate the importance of the non-careerist underpinnings of careers. Many of the 50\% to $70 \%$ of graduate students who survive to receive their $\mathrm{PhD}$, sustain their original commitment by doing public sociology on the side - often hidden from their supervisor. How often have I heard faculty advise their students to leave public sociology until after tenure - not realizing (or realizing all too well?) that public sociology is what keeps sociological passion alive. If they follow their advisor's advice, they may end up a contingent worker in which case there will be even less time for public sociology, or they may be lucky enough to find a tenure

6) Thanks to Stephen Steinberg for pointing out this coincidence. Although he played a major role in professionalizing sociology, Park did not give up social reform, and this despite his endorsement of detached social science and his proclaimed opposition to the action sociology of the women of Hull House.

7) The distinction between »public sociologist« and »public intellectual« is important - the former is a specialist variety of the latter, limiting public commentary to areas of established expertise rather than expounding on topics of broad interest (Gans 2002). 
track job, in which case they have to worry about publishing articles in accredited journals or publishing books with recognized university presses. Once they have tenure, they are free to indulge their youthful passions, but by then they are no longer youthful. They may have lost all interest in public sociology, preferring the more lucrative policy world of consultants or a niche in professional sociology. Better to indulge the commitment to public sociology from the beginning, and that way ignite the torch of professional sociology.

The differentiation of sociological labor with its attendant specialization can create anxiety for the sociological habitus that hankers after a unity of reflexive and instrumental knowledge, or a habitus that desires both academic and extra-academic audiences. The tension between institution and habitus drives sociologists restlessly from quadrant to quadrant, where they may settle for ritualistic accommodation before moving on, or abandon the discipline altogether. Still, there are always those whose habitus adapts well to specialization and whose energy and passion is infectious, spills over into the other quadrants. As I shall now argue specialization is not inimical to public sociology.

\section{Thesis VI: The Normative Model and its Pathologies}

\section{The flourishing of our discipline depends upon a shared ethos, underpinning the reci- procal interdependence of professional, policy, public and critical sociologies. In being over-responsive to their different audiences, however, each type of sociology can assume pathological forms, threatening the vitality of the whole.}

Those who have endorsed public sociology have often been openly contemptuous of professional sociology. Russell Jacoby's (1987) The Last intellectuals began a series of commentaries that lament the retreat of the public intellectual into a cocoon of professionalization. Thus, Orlando Patterson (2002) celebrates David Riesman as »The Last Sociologist, « because Riesman, and others of his generation, tackled issues of great public significance whereas professional sociology of today tests narrow hypotheses, mimicking the natural sciences. In asking »Whatever Happened to Sociology?«Peter Berger (2002) answers that the field has fallen victim to methodological fetishism and an obsession with trivial topics. But he also complains that the 1960s generation has turned sociology from a science into an ideology. He captures the cool reception of public sociology among many professional sociologists who fear public involvement will corrupt science, threaten the legitimacy of the discipline as well as the material resources it will have at its disposal.

I take the opposite view - that between professional and public sociology there should be, and there often is, respect and synergy. Far from being incompatible the two are like Siamese twins. Indeed, my normative vision of the discipline of sociology is of reciprocal interdependence among our four types - an organic solidarity in which each type of sociology derives energy, meaning, and imagination from its connection to the others.

As I have already insisted, at the heart of our discipline is its professional component. Without a professional sociology, there can be no policy or public sociology, but nor can there be a critical sociology - for there would be nothing to criticize. Equally professional sociology depends for its vitality upon the continual challenge of public issues through the vehicle of public sociology. It was the civil rights movement that transformed sociologists' understanding of politics, it was the feminist movement that gave new direction to so many spheres of sociology. In both cases it was sociologists, engaged with and participating in the movements, who infused new ideas into sociology. Similarly, Linda Waite's (2000) public defense of marriage, generated lively debate within our profession. Critical sociology may be a thorn in the side of professional sociology, but it is crucial in forcing awareness of the assumptions we make, so that from time to time we may change those assumptions. How 
bold and invigorating were Alvin Gouldner's (1970) challenges to structural functionalism, but also to the way policy sociology could become the unwitting agent of oppressive social control. Today we might include within the rubric of critical sociology the movement for »pure sociology, « a scientific sociology purged of public engagement. What was professional sociology yesterday can be critical today. Policy sociology, for its part, has reenergized the sociology of inequality with its research into poverty and education. More recently, medical research has married all four sociologies through collaboration with citizen groups around such illnesses as breast cancer, building new participatory models of science (Brown et al. 2004; McCormick et al. forthcoming).

Such examples of synergy are plentiful, but we should be wary of thinking that the integration of our discipline is easy. Connections across the four sociologies are often difficult to accomplish because they call for profoundly different cognitive practices, different along many dimensions - form of knowledge, truth, legitimacy, accountability, and politics, culminating in their own distinctive pathology. Table 3 highlights these differences.

Table 3. Elaborating the Types of Sociological Knowledge

\begin{tabular}{l|l|l}
\hline \hline & Academic & Extra-academic \\
\hline Instrumental & Professional sociology & Policy sociology \\
Knowledge & Theoretical/empirical & Concrete \\
Truth & Correspondence & Pragmatic \\
Legitimacy & Scientific norms & Effectiveness \\
Accountability & Peers & Clients \\
Politics & Professional self-interest & Policy intervention \\
Pathology & Self-referentiality & Servility \\
Reflexive & Critical sociology & Public sociology \\
Knowledge & Foundational & Communicative \\
Truth & Normative & Consensus \\
Legitimacy & Moral vision & Relevance \\
Accountability & Critical intellectuals & Designated publics \\
Politics & Internal debate & Public dialogue \\
Pathology & Dogmatism & Faddishness \\
\hline
\end{tabular}

The knowledge we associate with professional sociology is based on the development of research programs, different from the concrete knowledge required by policy clients, different from the communicative knowledge exchanged between sociologists and their publics, which in turn is different from the foundational knowledge of critical sociology. From this follows the notion of truth to which each adheres. In the case of professional sociology the focus is on producing theories that correspond to the empirical world, in the case of policy sociology knowledge has to be »practical« or »useful, « whereas with public sociology knowledge is based on consensus between sociologists and their publics, while for critical sociology truth is nothing without a normative foundation to guide it. Each type of sociology has its own legitimation: professional sociology justifies itself on the basis of scientific norms, policy sociology on the basis of its effectiveness, public sociology on the basis of its relevance and critical sociology has to supply moral visions. Each type of sociology also has its own accountability. Professional sociology is accountable to peer review, policy sociology to its clients, public sociology to a designated public, whereas critical sociology is accountable to a community of critical intellectuals who may transcend disciplinary boundaries. Furthermore, each type of sociology has its own politics. Professional sociology defends the conditions of science, policy sociology proposes policy interventions, public sociology understands politics as democratic dialogue whereas critical sociology is committed to opening up debate within our discipline. 
Finally, and most significantly, each type of sociology suffers from its own pathology, arising from its cognitive practice and its embeddedness in divergent institutions. Those who speak only to a narrow circle of fellow academics easily regress toward insularity. In the pursuit of the puzzle solving, defined by our research programs, professional sociology can easily become focused on the seemingly irrelevant. ${ }^{8}$ In our attempt to defend our place in the world of science we do have an interest in monopolizing inaccessible knowledge, which can lead to incomprehensible grandiosity or narrow »methodism«. No less than professional sociology, critical sociology has its own pathological tendencies toward ingrown sectarianism - communities of dogma that no longer offer any serious engagement with professional sociology or the infusion of values into public sociology. On the other side, policy sociology is all too easily captured by clients who impose strict contractual obligations on their funding, distortions that can reverberate back into professional sociology. If market research had dominated the funding of policy sociology, as Mills feared it would, then we could all be held to ransom. The migration of sociologists into business, education and policy schools may have tempered this pathology but certainly not insulated the discipline from such pressures. Public sociology, no less than policy sociology, can be held hostage to outside forces. In pursuit of popularity public sociology is tempted to pander to and flatter its publics, and thereby compromising professional and critical commitments. There is, of course, the other danger that public sociology speak down to its publics, a sort of intellectual vanguardism. Indeed, one might detect such a pathology in C. Wright Mills's contempt for mass society.

These pathologies are real tendencies so that the critical views of Jacoby, Patterson, Berger and others with regard to professional sociology are not without foundation. These critics err, however, in reducing the pathological to the normal. They conveniently miss the important, relevant research of professional sociology, showcased, for example, in the pages of Contexts just as they overlook the pathologies of their own types of sociology. The professionals are no less guilty of pathologizing public sociology as »pop sociology, « while overlooking the ubiquitous and robust but, often, less accessible public sociology. As a community we have too easily gone to war with each »other, « blind to the necessary interdependence of our divergent knowledges. We need to bind ourselves to the mast, making our professional, policy, public and critical sociologies mutually accountable. In that way we would also contain the development of pathologies. Institutionalizing reciprocal interchange would also require us to develop a common ethos that recognizes the validity of all four types of sociology - a commitment based on the urgency of the problems we study. In this best of all worlds, in this normative vision, one would not have to be a public sociologist to contribute to public sociology, one could do so by being a good professional, critical or policy sociologist. The flourishing of each sociology would enhance the flourishing of all.

\section{Thesis VII: The Discipline as a Field of Power}

\section{In reality disciplines are fields of power in which reciprocal interdependence becomes asymmetrical and antagonistic. The result, at least in the United States, is a form of domination in which instrumental knowledge prevails over reflexive knowledge.}

Our angel of history, having aroused himself in the 1970s, was swept back in another storm during the 1980s. Sociology was in crisis - undergraduate enrollments plummeted, the job situation for qualified sociologists worsened, there were rumors of department closures, and intellectually the discipline seemed to lose direction. From the pen of Irving Louis Horowitz

8) I say »seemingly« irrelevant because first and foremost one's research program defines what is anomalous or contradictory. If the results may seem trivial, then the research program itself must bear the burden of relevance and insight. 
(1993) came The Decomposition of Sociology complaining of the politicization of sociology. James Coleman $(1991,1992)$ devoted articles to the dangers of political correctness and the invasion of the academy by the social norm. Stephen Cole's (2001) edited collection, What's Wrong with Sociology? brought together such distinguished sociologists as Peter Berger, Joan Huber, Randall Collins, Seymour Martin Lipset, James Davis, Mayer Zald, Arthur Stinchcombe, and Howard Becker. They mourned sociology's fragmentation, incoherence, non-cumulativeness as though a true science - using their image of natural science or economics - is always integrated, coherent and cumulative! Their 1950s optimism had turned sour in the face of the barrage of critical challenges to consensus sociology during the 1960s and 1970s. Now the chickens were coming home to roost and sociology, or their vision of it, was in jeopardy

Perhaps the most interesting and thorough-going of this genre of writing was Stephen Turner and Jonathan Turner's (1990) The Impossible Science that reconstructed the history of sociology from this bleak standpoint. From the beginning, they aver, sociology had neither a sustainable audience nor reliable clients and patrons. It was continually overrun by political forces, interrupted by a transitory scientific ascendancy in the period after World War Two. If there is a common thread running through all these narratives of decline it is one that attributes sociology's malaise to the subversive power of its reflexive knowledge, whether this be in the form of critical or public sociology.

In one respect I concur with the »declinists «: our discipline is not only a potentially integrated division of labor but also a field of power, a more or less stable hierarchy of antagonistic knowledges. My disagreement, however, lies with their evaluation of the state of sociology and the balance of power within our discipline. Sociology's decline in the 1980s was short lived. Far from being in the doldrums, today sociology has never been in better shape. The numbers of BAs in sociology has been increasing steadily since 1985, overtaking economics and history and nearly catching up with political science. The production of $\mathrm{PhDs}$ still lags behind these neighboring disciplines, but our numbers have been growing steadily since 1989. They will, presumably, continue to grow to meet the demand for undergraduate teaching, although the trend toward adjunct and contingent labor shows no sign of abating. Membership of the American Sociological Association has been mounting rapidly for the last four years, restoring the all time highs of the 1970s. Given a political climate hostile to sociology this is perhaps strange, yet it could be that this very climate is drawing people to the critical and public moments of sociology.

My second point of disagreement with the »declinists « concerns the threat to sociology. I believe it is the reflexive dimension of sociology that is in danger not the instrumental dimension. At least in the United States professional and policy sociologies - the one supplying careers and the other supplying funds - dictate the direction of the discipline. Critical sociology's supply of values and public sociology's supply of influence do not match the power of careers and money. There may be dialogue along the vertical dimension of Table 1 , but the real bonds of symbiosis lie in the horizontal direction, creating a ruling coalition of professional and policy sociology and a subaltern mutuality of critical and public sociology. This pattern of domination derives from the embeddedness of the discipline in a wider constellation of power and interests. In our society money and power speak louder than values and influence. In the United States capitalism is especially raw with a public sphere that is not only weak but overrun by armies of experts and a plethora of media. The sociological voice is easily drowned out. Just as public sociology has to face a competitive public sphere, so critical sociology encounters the balkanization of disciplines, and as a result critical discussion is deprived of access to its most powerful engine - parallel dispositions in other disciplines. 
The balance of power may be weighted in favor of instrumental knowledge, but we can still make our discipline ourselves, creating the spaces to manufacture a bolder and more vital vision. To be sure there is a contradiction between professional sociology's accountability to peers and public sociology's accountability to publics, but must this lead to warring camps - each pathologizing the other? To be sure critical and policy sociologies are at odds - the one clinging to its autonomy and the other to its clients - but if each would recognize parts of the other in itself, mutuality could displace antagonism. Instead of driving the discipline into separate spheres we might develop a variety of synergies and fruitful engagements.

Here there is no space to explore any further the potential antagonisms and alliances within this field of power. Suffice to say, if our discipline can be held together only under a system of domination, let that system be one of hegemony rather than despotism. That is to say the subaltern knowledges (critical and public) should be allowed breathing space to develop their own capacities and to inject dynamism back into the dominant knowledges. Professional and policy sociology should recognize their enlightened interest in flourishing critical and public sociologies. However disruptive in the short term, in the long term instrumental knowledge cannot thrive without challenges from reflexive knowledges, that is, from the renewal and redirection of the values that underpin their research, values that are drawn from and recharged by the wider society.

We have sketched out the field of power that comprises the relations among the four sociologies in a relatively abstract manner. Their concrete combination will vary among departments, over time within a single country, among countries, and even assume a changing global configuration. Accordingly, the next three theses explore the specificity of the contemporary configuration of United States sociology by pursuing a series of comparisons and in this way we will deepen our encounter with the national and global forces shaping disciplinary fields.

\section{Thesis VIII: History and Hierarchy}

In the United States the domination of professional sociology emerged through successive dialogues with public, policy and critical sociologies. But even here the strength of professional sociology is concentrated in the research departments at the top of a highly stratified system of university education while at the subaltern levels public sociology is often more important if less visible.

Today we accept the domination of professional sociology as a normal feature of United States sociology but it is actually a quite recent phenomenon. We can plot the history of United States sociology as the deepening of professional sociology in three successive periods.

Professional sociology began in the middle of the 19th. century as a dialogue between ameliorative, philanthropic and reform groups on the one side, and the early sociologists on the other side. The latter often came from a religious background but they transferred their moral zeal to the fledgling secular science of sociology. After the Civil War the exploration of social problems developed through the collection and analysis of labor statistics as well as social surveys of the poor. Collecting data to demonstrate the plight of the lower classes became a movement unto itself that laid the foundations of professional sociology. Sociologists would remain in close contact with all manner of groups in a burgeoning civil society even after the formation of American Sociological Society, as it was called then, in 1905. In its origins, therefore, sociology was inherently public.

The second phase of sociology saw the shift of engagement from publics to foundations and government. Beginning in the 1920s with the Rockefeller Foundation's support for the 
Institute for Social and Religious Research (which would sponsor the famous Middletown studies) and then its support for community research at the University of Chicago and at the University of North Carolina, foundations became increasingly active in promoting sociology. At the same time rural sociology managed to create a research base within the state itself (Larson and Zimmerman 2003). As director of the President's Research Committee (1933), William Ogburn pulled together a massive volume on Recent Social Trends in the United States. During World War II, state sponsored sociology continued, the most famous being Samuel Stouffer's (1949) multi-volume study of morale within the United States army. After the war a new source of funding appeared, namely the corporate financing of survey research, epitomized by Lazarsfeld's work at the Bureau of Applied Social Research at Columbia University. The more sociology depended upon commercial and government funding the more it developed rigorous statistical methods for the analysis of empirical data, which invited criticisms from many quarters.

The third phase of American sociology, therefore, was marked by critical sociology's engagement with professional sociology. Its inspiration was Robert Lynd (1939) who criticized sociology's narrowing of scope and its claims of value neutrality. It was perhaps most famously continued by C. Wright Mills (1959), who referred to sociology's originating engagement with publics as »liberal practicality « and to the second period of corporate and state funding as »illiberal practicality.« He did not realize, however, that he was inaugurating a third phase of »critical sociology, « which would redirect both theoretical and methodological trends within the discipline. Alvin Gouldner (1970) produced a milestone in this third phase, attacking the foundations of structural functionalism and allied sociologies, and creating space for new theoretical tendencies influenced by feminism and Marxism. This critical sociology provided the energy and imagination behind the reconstruction of professional sociology in the 1980s and 1990s.

From where will the next impetus for sociology come? Thesis I claimed that the gap between the sociological ethos and the world is propelling sociology into the public arena. Moreover, professional sociology has now reached a level a maturity and self confidence that it can return to its civic roots, and promote public sociology from a position of strength - an engagement with the profound and disturbing global trends of our time. If the original public sociology of the 19th. century was inevitably provincial, it nonetheless laid the foundation for the ambitious professional sociology of the 20th. century, which, in turn, has created the basis for its own transcendence - a 21 st century public sociology of global dimensions.

This is not to discount the importance of local public sociology, the organic connections between sociologists and immediate communities. Far from it. After all the global only manifests itself through and is constituted out of local processes. We must recognize that so much local public sociology is already taking place in our state systems of education where faculty bear the burden of huge teaching loads. If they can squeeze some time beyond teaching, they take their public sociology out of the classroom and into the community. We do not know about these extra-curricular public sociologies because their practitioners rarely have the time to write them up. Fortunately, Kerry Strand, Sam Marullo, Nick Cutforth, Randy Stoecker and Patrick Donohue (2003) have cast a beam on to this hidden terrain by putting together a handbook on organic public sociologies or what they call community-based research. The volume lays out a set of principles and practices as well as numerous examples, many of which combine research, teaching and service.

The broader point is that the US system of higher education is a large sprawling set of institutions, steeply hierarchical and enormously diverse. Therefore, the configuration of our four sociologies looks very different at different levels and in different places. The concentration of research and professionalism in the upper reaches of our university system is made 
possible, at least in part, by the overburdening of our teaching institutions, the four-year and two-year colleges. The configuration of sociologies in these institutions is analogous to that in poorly resourced parts of the world. As the next thesis intimates diversity within the United States mirrors diversity at the global level.

\section{Thesis IX: Provincializing American Sociology}

\section{United States sociology presents itself as universal, but it is particular - not just in its content but also in its form, that is, in its configuration of our four types of sociology. At the same time it exercises enormous influence over other national sociologies, and not always to their advantage. Thus, we need to remold not only the national but also the global division of sociological labor.}

The term »public sociology« is an American invention. If, in other countries, it is the essence of sociology, for us it is but a part of our discipline, and a small one at that. Indeed, for some U.S. sociologists it does not belong in our discipline at all. When I travel to South Africa, however,, to talk about public sociology - and this would be true of many countries in the world - my audiences look at me nonplussed. What else could sociology be, if not an engagement with diverse publics about public issues? That the American Sociological Association would devote our annual meetings to public sociologies speaks volumes about the strength of professional sociology in the United States. Moreover, in a world where national professional sociologies are often weaker than public sociologies, focusing on the latter signifies a challenge to the international hegemony of United States sociology, and points toward sociology's reconstruction nationally and globally.

The configuration of our four types of sociology varies from country to country. In the Global South, as I have intimated, sociology has often a strong public presence. Visiting South Africa in 1990 I was surprised to discover the close connection between sociology and the anti-apartheid struggles, especially the labor movement but also diverse civic organizations. While in the United States we were theorizing social movements, in South Africa sociologists were making social movements! This project drove their sociology, stimulating a whole new field of research - social movement unionism - which U.S. sociologists rediscovered, as though it were a brand new idea, 20 years later! But South African sociology not only focused on social mobilization but on the targets of such mobilization. Sociologists analyzed the character and tendencies of the apartheid state, debated the strategy of the antiapartheid movement. They asked whether they should be servants or critics of the movement. Today, however, ten years after apartheid South Africa presents a less favorable context for public sociology, as sociologists are drawn off into NGOs, corporations or state apparatuses, as the new government calls on sociologists to withdraw from the trenches of civil society and focus on teaching, and as social research is channeled into immediate policy issues or »bench-marked « to »international, «i.e. American, professional standards. The demobilization of civil society has gone hand in hand with a shift from reflexive to instrumental sociology (Sitas 1997; Webster 2004).

Similar tendencies can be found elsewhere, but each with their national specificity. Take the Soviet Union. Sociology disappeared underground in the Stalin era, only to resurface as a weapon of official and unofficial critique under the post-Stalin regimes. Opinion research became a form of public sociology during the thaw of the 1960s before it was monopolized by the party apparatus. Under the stalwart leadership of Tatyana Zaslavskaya, Perestroika brought sociologists out in force. Sociology became intimately connected to the eruption of civil society. With the evisceration of civil society in the post-Soviet period, however, the fledgling sociology proved defenseless against the invasion of market forces. With but a few 
exceptions sociology was banished to business schools and to centers of opinion and market research. Where it exists as a serious intellectual enterprise, it is often funded by Western foundations, employing sociologists trained in England or the United States.

The situation is very different in Scandinavian countries with their strong social democratic traditions. Here sociology grew up with the welfare state, which conferred a strong policy orientation but an equally strong public moment. Norwegian sociology, very much influenced by American sociology, was nonetheless also geared to the policy world and here the feminist input was very important. With a population of only 5 million and less than 200 registered sociologists the professional community is small, so that the more ambitious seek a place in the wider society whether in government or as public intellectuals. They are regular contributors to newspapers, radio and television. Norwegians have energetically taken their public sociologies abroad, becoming an international hub with links not to just to the United States but to Europe and countries of the Global South.

The rest of Europe is quite variable. France has one of the longest traditions of professional sociology, and at the same time cultivated a traditional public sociology, with such leading lights as Raymond Aron, Pierre Bourdieu and Alain Touraine. In England professional sociology is of a more recent, post-World War Two, vintage, easily vulnerable to the Thatcher regime that sought to muzzle public and policy initiatives while strengthening a parochial inward looking profession. The return of a Labour government gave sociology a new lease of life, expanding the sphere of policy research and propelling its most illustrious and prolific public sociologist, Anthony Giddens, into the House of Lords.

In mapping the fields of national sociologies one learns not only how particular is the sociology of the United States but also how powerful and influential it is. Turning out 600 doctorates a year, it strides like a giant over world sociology. Many of the leading sociologists, teaching in other parts of the world, were trained in the United States. The American Sociological Association has almost 14,000 members with 24 full time staff. But it is not simply the domination of numbers and resources but, increasingly, governments around the world are holding their own academics, sociologists included, accountable to »international « standards, which means publishing in »Western, « journals, and in particular American journals. It's happening in South Africa and Taiwan but also in countries with considerable resources, such as Norway. Driven by connections to the West and publishing in English, national sociologies lose their engagement with national problems and local issues. Within each country, states nurture global pressures, which fracture the national division of sociological labor, driving wedges among the four sociologies.

Without conspiracy or deliberation on the part of its practitioners, United States sociology becomes world hegemonic. We, therefore, have a special responsibility to provincialize our own sociology, to bring it down from the pedestal of universality and recognize its distinctive character and national power. We have to develop a dialogue, once again, with other national sociologies, recognizing their local traditions or their aspirations to indigenize sociology. We have to think in global terms, to recognize the emergent global division of sociological labor. If the United States rules the roost with its professional sociology, then we have to foster public sociologies of the Global South and the policy sociologies of Europe. We have to encourage networks of critical sociologies that transcend not just disciplines but also national boundaries. We should apply our sociology to ourselves, become more conscious of the global forces that are driving our discipline, so that we may channel them rather than be channeled by them. 


\section{Thesis X: Dividing the Disciplines}

The social sciences distinguish themselves from the humanities and the natural sciences by their combination of both instrumental and reflexive knowledge - a combination that is itself variable, and thereby giving different opportunities for public and policy interventions. Interdisciplinary knowledge takes different forms in each quadrant of the sociological field.

It is said that the division of the disciplines is an arbitrary product of 19th. century European history, that the present disciplinary specialization is anachronistic, and that we should move ahead toward a unified social science. This positivist fantasy was recently resurrected by Immanuel Wallerstein et al. (1996) in the Report of the Gulbenkian Commission on the Restructuring of the Social Sciences. The project looks harmless enough but in failing to pose the questions - knowledge for whom? and knowledge for what? - the new unified social science all too easily dissolves reflexivity, that is, the critical and public moments of social science. In a world of domination unity too easily becomes the unity of the powerful. To declare the division of the disciplines as arbitrary, just because they were created at a particular moment of history, is to miss their ongoing and changing meaning and the interests they represent. It is to commit the genetic fallacy. In order to underline the grounds for the division of the disciplines, and in the interests of brevity, I fall back on schematic portraits of academic fields, inevitably sacrificing attention to both internal differentiation and variation over time and place.

The natural sciences are largely based on instrumental knowledge, rooted in research programs whose development is governed by scientific communities. The extra-academic audience is from the policy world - industry or government - ready to exploit scientific discoveries. Increasingly, this extra-academic audience enters the academy to direct or oversee its research, prompting opposition to collusive relations, whether these be in the area of medical research, nuclear physics or bioengineering (Epstein 1996; Moore 1996; Schurman and Munro 2004). Such critical reflexivity, often extending into public debate, is not the essence of natural science as it is of the humanities. Thus, works of art or literature are ultimately validated on the basis of a dialogue among narrower groups of cognoscenti or within broader publics. Their truth is established through their aesthetic value based on discursive evaluation, that is, as critical and public knowledges, although, of course, they may be elaborated into schools of instrumental knowledge and even enter the policy world.

The social sciences are at the crossroads of the humanities and the natural sciences since in their very definition they partake in both instrumental and reflexive knowledge. The balance between these two types of knowledge, however, varies among the social sciences. Economics, for example, is as close as the social sciences get to what we might call a paradigmatic science, dominated by a single research program (neo-classical economics). The organization of the discipline reflects this with its paucity of prizes (Clark Medal and Nobel Prize), elite control of the major journals, clear rankings not just of departments but of individual economists, and the absence of autonomously organized subfields. Dissident economists survive only if they can first establish themselves in professional terms. Indeed, one might liken professional economics to the discipline of the Communist Party with its dissidents and its coherent doctrine that it seeks to spread the world over, all in the name of freedom. ${ }^{9}$ The internal

9) Marion Fourcade-Gourinchas (2004) documents the enormous international influence of American economics. Working off the ideas of Amartya Sen (1999), Peter Evans (2004) has striven valiantly to push economics toward an organic public engagement, an economics sensitive to local issues and deliberative democracy. 
coherence of economics gives it greater prestige within the academic world and greater effectiveness in the policy world.

If economics is like the Communist Party, American sociology is more like Anarcho-Syndicalism, a decentralized participatory democracy. It is based on multiple and overlapping research traditions, reflected in its very active 43 sections and their ever proliferating awards (Ennis 1992), and in the over-200 sociology journals (Turner and Turner 1990: 159). Our institutional mode of operation reflects our multiple perspectives - although not always adequately. The discipline, a hierarchical and elitist caste system though it is (Burris 2004), nonetheless is more open than economics as measured by faculty mobility between departments and the patterns of recruitment of graduate students (Han 2003). The discipline is more democratic in its elections of officers. Member resolutions are not restricted to professional concerns, and they require the support of only $3 \%$ of the membership to be put to a vote. Thus, if economics is more effective in the policy world, the structure of the discipline of sociology is organized to be responsive to diverse publics. To the extent that our comparative advantage lies in the public sphere, we are more likely to influence policy indirectly via our public engagements.

Looking at the other social sciences, political science is a balkanized field but one more inclined toward policy than publics, toward instrumental rather than reflexive knowledge. Today tendencies toward rational choice modeling have led to a reaction in a reflexive direction. The Perestroika Movement within political science upholds a more institutional approach to politics, and buttresses political theory as critical theory. Anthropology and geography are balkanized across the instrumental-reflexive divide, so that cultural anthropology and human geography often react against the scientific models of their colleagues, while serving as bridges to the humanities. Philosophy, another cross-over between social sciences and humanities, finds its distinctive niche in critical knowledge.

Disciplinary divides are far stronger in the United States than elsewhere, so that »interdisciplinary « knowledge leads a precarious existence at the boundaries of our disciplines. Each of the four types of sociology develops a distinctive exchange and collaboration with neighboring disciplines. At the interface of professional knowledge there is a cross-disciplinary borrowing. When economic sociology and political sociology borrow from the neighboring disciplines the result is still distinctively part of sociology - the social bases of markets and politics. At the interface of critical knowledge, there is a trans-disciplinary infusion. Feminism, poststructuralism and critical race theory have all left their mark on critical sociology's engagement with professional sociology. But the infusion has always been limited. The development of public knowledge often comes about through multi-disciplinary collaboration as, for example, in »participatory action research « that brings communities together with academics from complementary disciplines. A community defines an issue - public housing, environmental pollution, disease, living wage, schooling, etc. - and then works together with a multi-disciplinary team to frame and formulate approaches. Finally, in the policy world there is joint-disciplinary coordination, which often reflects a hierarchy of disciplines. Thus, state funded area studies often worked with well-defined policy goals that gave precedence to political science and economics.

Having recognized the power of the disciplinary divide, captured in varying combinations of instrumental and reflexive knowledge, we must now ask what this variation signifies? Specifically, is there anything distinctive about sociological knowledge and the interests it represents? Might we as well be economists or political scientists and by happenstance we end up as sociologists - a matter of little consequence, a biographical accident? Do we have an identity of our own among the social sciences? This brings me to my final thesis. 


\section{Thesis XI: Sociologist as Partisan ${ }^{10}$}

If the standpoint of economics is the market and its expansion, and the standpoint of political science is the state and the guarantee of political stability, then the standpoint of sociology is civil society and the defense of the social. In times of market tyranny and state despotism, sociology - and in particular its public face-defends the interests of humanity.

The social sciences are not a melting pot of disciplines, because the disciplines represent different and opposed interests - first and foremost interests in the preservation of the grounds upon which their knowledge stands. Economics, as we know it today, depends on the existence of markets with an interest in their expansion, political science depends on the state with an interest in political stability, while sociology depends on civil society with an interest in the expansion of the social.

But what is civil society? For the purposes of my argument here we can define it as a product of late 19th. century Western capitalism that produced associations, movements and publics that were outside both state and economy - political parties, trade unions, schooling, communities of faith, print media and a variety of voluntary organizations. This congeries of associational life is the unique standpoint of sociology so that when it disappears - Stalin's Soviet Union, Hitler's Germany, Pinochet's Chile - sociology disappears too. When civil society flourishes - Perestroika Russia or late Apartheid South Africa - so does sociology.

Sociology may be connected to society by an umbilical cord, but, of course, this is not to say sociology only studies civil society. Far from it. But it studies the state or the economy from the standpoint of civil society. Political sociology, for example, is not the same as political science. It examines the social preconditions of politics and the politicization of the social just as economic sociology is very different from economics, indeed it looks at what economists overlook, the social foundations of the market.

This tripartite division of the social sciences - I have no space here to include such neighbors as geography, history and anthropology - was true of their birth in the 19th. century, but it became blurred in the 20th. century (with the fusing and overlapping boundaries of state, economy and society). For the last 30 years, however, this three-way separation has been undergoing renaissance, speared-headed by state unilateralism on the one side and market fundamentalism on the other. Through this period civil society has been colonized and co-opted by markets and states. Still, opposition to these twin forces comes, if it comes at all, from civil society, understood in its local, national and transnational expressions. In this sense sociology's affiliation with civil society, that is public sociology, represents the interests of humanity - interests in keeping at bay both state despotism and market tyranny.

Let me immediately qualify what I've said. First, I do believe that economics and political science, between them, have manufactured the ideological time bombs that have justified the excesses of markets and states, excesses that are destroying the foundations of the public university, that is, their own academic conditions of existence, as well as so much else. Still, while acknowledging this I would not want to write off all political scientists and economists. Disciplines, after all, are fields of power, each with its dominant and oppositional

10) Taken from Alvin Gouldner's (1968) essay of the same title. Equally pertinent to Thesis XI are the challenging words of Pierre Bourdieu: »The ethnosociologist is a sort of organic intellectual of humankind who, as a collective agent, can contribute to denaturalizing and defatalizing existence by putting her competency at the service of a universalism rooted in the understanding of particularisms.« Cited in Wacquant (2004) 
forces. Think of the Perestroika Movement in political science or the network of Post-Autistic Economics - an economics that recognizes individuals as mature and multi-faceted human beings. As sociologists we can find and, indeed, have found allies in and collaborated with these oppositional formations.

The field of sociology is also divided. Civil society, after all, is not some harmonious communalism but it is riven by segregations, dominations, and exploitations. ${ }^{11}$ Historically, civil society has been male and white. As it has become more inclusive it has also been invaded by state and market, reflected in sociology by the uncritical use of such concepts as social capital. Civil society is very much a contested terrain but still, I would argue, in the present conjuncture the best possible terrain for the defense of humanity - a defense that would be aided by the cultivation of a critically disposed public sociology.

How can we accomplish this goal? As I have already suggested in Thesis VII the institutional division of sociological labor and the corresponding field of power have hitherto restricted the expansion of public sociologies. We would not have to defend public sociology if there were not obstacles to its realization. To surmount them requires commitment and sacrifice that many have already made and continue to make. That was why they became sociologists - not to make money but a better world. So, there already exist a plethora of public sociologies. But there are also new developments. Thus, the magazine Contexts has taken a major step in the direction of public sociology. The ASA head office has made vigorous efforts in outreach and lobbying, with its congressional briefings and its regular press releases, but also in the columns of our newsletter Footnotes. This year the ASA has introduced a new award that will recognize excellence in the reporting of sociology in the media. We need to cultivate a collaborative relation between sociology and journalism, for journalists are a public unto themselves as well as standing between us and a multitude of other publics.

The ASA has also established a task force for the institutionalization of public sociologies, which will consider three key issues. First, it will consider how to recognize and validate the public sociology that already exists, making the invisible visible, making the private public. Second, the task force will consider how to introduce incentives for public sociology, to reward the pursuit of public sociology that is so often slighted in merits and promotions. Already departments have created awards and blogs, and have begun designing course syllabi for public sociology. Third, if we are going to acknowledge and reward public sociology then we must develop criteria to distinguish good from bad public sociology. And we must ask who should evaluate public sociology. We must encourage the very best of public sociology whatever that may mean. Public sociology cannot be second rate sociology.

Important though these institutional changes are, the success of public sociology will not come from above but from below. It will come when public sociology captures the imagination of sociologists, when sociologists recognize public sociology as important in its own right with its own rewards, and when sociologists then carry it forward as a social movement beyond the academy. I envision myriads of nodes, each forging collaborations of sociologists with their publics, flowing together into a single current. They will draw on a century of extensive research, elaborate theories, practical interventions, and critical thinking, reaching common understandings across multiple boundaries, not least but not only across national

11) It is here that I part company with the Durkheimian perspective of communitarians, such as Amitai Etzioni (1993) and Philip Selznick (2002), who focus on the moral relation of individual to society and who regard hierarchies, dominations, exclusions, etc. as unfortunate interferences. Just as they do not center the divisions of society they also side step divisions within sociology and within the academy more generally. 
boundaries, and in so doing shedding insularities of old. Our angel of history will then spread her wings and soar above the storm.

\section{References}

Abbott, Andrew, 2001: Chaos of Disciplines. Chicago, IL: University of Chicago Press.

American Sociological Association, 2004: An Invitation to Public Sociology. Washington, DC: American Sociological Association.

Arendt, Hannah, 1958: The Human Condition. Chicago, IL: University of Chicago Press.

Bellah, Robert/ Richard Madsen/ William M. Sullivan/ Ann Swidler/ Steven Tipton, 1985: Habits of the Heart: Individualism and Commitment in American Life. Berkeley, CA: University of California Press.

Benjamin, Walter, 1968: Illuminations. Edited and with an introduction by Hannah Arendt. New York: Harcourt Brace Jovanovich.

Berger, Peter, 2002: »Whatever Happened to Sociology.« First Things 126:27-29.

Bielby, William, 2003: Betty Dukes, et al. v. Wal-Mart Stores, Inc.

Blau, Peter/ Otis Dudley Duncan, 1967: The American Occupational Structure. New York: John Wiley.

Bok, Derek, 2003: Universities in the Marketplace. Princeton, NJ: Princeton University Press.

Bourdieu, Pierre, 1986 [1979]: Distinction: A Social Critique of the Judgment of Taste. New York: Routledge and Kegan Paul.

Bourdieu, Pierre, 1988 [1984]: Homo Academicus. Stanford, CA: Stanford University Press.

Brown, Phil/ Stephen Zavestoski/ Sabrina McCormick/ Brian Mayer/ Rachel Morello-Frosch/ Rebecca Gasio Altman, 2004. »Embodied Health Movements: New Approaches to Social Movements in Health.« Sociology of Health and Illness 26:50-80.

Burris, Val, 2004: $\gg$ The Academic Caste System: Prestige Hierarchies in PhD Exchange Networks.«American Sociological Review 69: 239-264.

Cole, Stephen (ed), 2001: What's Wrong with Sociology? New Brunswick, NJ: Transaction Publishers.

Coleman, James, 1966: Equality of Educational Opportunity. Washington, DC: United States Department of Health, Education and Welfare.

Coleman, James, 1975: Trends in School Segregation, 1968-1973. Washington, DC: Urban Institute,

Coleman, James, 1991: »A Quiet Threat to Academic Freedom.« National Review 43:28-34.

Coleman, James, 1992: »The Power of Social Norms.«Duke Dialogue 3.

Collins, Patricia Hill, 1991: Black Feminist Thought. New York: Routledge.

Columbia Accident Investigation Board, 2003: Report. Vol. I. Washington, DC: Government Printing Office.

Dewey, John, 1927: The Public and Its Problems. New York: Henry Holt.

Du Bois, W.E.B, 1903: The Souls of Black Folk. New York: A.C. McClurg.

Ehrenreich, Barbara, 2002: Nickel and Dimed. New York: Henry Holt.

Ennis, James, 1992: »The Social Organization of Sociological Knowledge: Modeling the Intersection of Specialties.«American Sociological Review 57:259-65.

Epstein, Steven, 1996: Impure Science. Berkeley, CA: University of California Press.

Etzioni, Amitai, 1993: The Spirit of Community. New York: Simon and Schuster.

Evans, Peter, 2004: »Development as Institutional Change: The Pitfalls of Monocropping and the Potentials of Deliberation. « Studies in Comparative International Development 38:30-53.

Fourcade-Gourinchas, Marion, 2004: »The Construction of a Global Profession: The Case of Economics, « Department of Sociology, University of California, Berkeley, CA. Unpublished manuscript.

Fraser, Nancy, 1997: Justice Interruptus. New York: Routledge.

Gamson, William, 2004: »Life on the Interface.« Social Problems 51:106-10. 
Gans, Herbert, 2002: »More of Us Should Become Public Sociologists.«Footnotes (July/August) 30:10.

Goodwin, Jeff/ Jim Jasper, eds., 2004: Rethinking Social Movements. Lanham, MD: Rowman and Littlefield.

Gouldner, Alvin, 1968: »The Sociologist as Partisan: Sociology and the Welfare State.« American Sociologist 3:103-16.

Gouldner, Alvin, 1970: The Coming Crisis of Western Sociology. New York: Basic Books.

Habermas, Jürgen, 1984: The Theory of Communicative Action. (Two Volumes). Boston, MA: Beacon.

Habermas, Jürgen, 1991 [1962]: The Structural Transformation of the Public Sphere. Cambridge, MA: MIT Press.

Han, Shin-Kap, 2003: »Tribal Regimes in Academia: A Comparative Analysis of Market Structure Across Disciplines. « Social Networks 25:251-80.

Horkheimer, Max, 1974 [1947]: Eclipse of Reason. New York: Seabury Press.

Horkheimer, Max/ Theodor Adorno, 1969 [1944]: Dialectic of Enlightenment. New York: Seabury Press.

Horowitz, Irving Louis, 1993: The Decomposition of Sociology. New York: Oxford University Press.

Jacoby, Russell, 1987: The Last Intellectuals : American Culture in the Age of Academe. New York: Noonday Press.

Kang, Kelly, 2003: Characteristics of Doctoral Scientists and Engineers in the United States: 2001. Arlington, VA: National Science Foundation. Division of Science Resources Statistics.

Kirp, David, 2003: Shakespeare, Einstein, and the Bottom Line. Cambridge, MA: Harvard University Press.

Lakatos, Imre, 1978: The Methodology of Scientific Research Programmes. Cambridge, England: Cambridge University Press.

Larson, Olaf/ Julie Zimmerman, 2003: Sociology in Government: The Galpin-Taylor Years in the U.S. Department of Agriculture 1919-1953. University Park, PA: University of Pennsylvania Press.

Lee, Alfred McClung, 1976: »Sociology for Whom?« American Sociological Review 41:925-36.

Lippmann, Walter, 1922: Public Opinion. New York: Harcourt, Brace and Company.

Lipset, Seymour Martin/ Neil J. Smelser, 1961: Sociology: The Progress of a Decade. Englewood Cliffs, NJ: Prentice-Hall.

Lyman, Stanford, 1992: Militarism, Imperialism, and Racial Accommodation: An Analysis and Interpretation of the Early Writings of Robert E. Park. Fayetteville, AK: University of Arkansas Press.

Lynd, Robert, 1939: Knowledge for What? The Place of Social Sciences in American Culture. Princeton, NJ: Princeton University Press.

Marullo, Sam/ Bob Edwards (eds.), 2000: »Service-Learning Pedagogy as Universities' Response to Troubled Times. « Special issue of American Behavioral Scientist 43:741-912.

McCormick, Sabrina, Julia Brody, Phil Brown/ Ruth Polk. Forthcoming: »Public Involvement in Breast Cancer Research: An Analysis and Model for Future Research.«International Journal of Health Services.

Merton, Robert, 1949: Social Theory and Social Structure. Glencoe, IL: Free Press.

Mills, C. Wright, 1959: The Sociological Imagination. New York: Oxford University Press.

Moore, Kelly, 1996: »Organizing Integrity: American Science and the Creation of Public Interest Organizations, 1955-1975.« American Journal of Sociology 101:1592-1627.

Mueller, John, 1973: War, Presidents and Public Opinion. New York: John Wiley.

Myrdal, Gunnar, 1944: An American Dilemma: The Negro Problem and Modern Democracy. New York: Harper and Row.

Ostrow, James, Garry Hesser/ Sandra Enos (eds.), 1999: Cultivating the Sociological Imagination: Concepts and Models for Service-Learning in Sociology. Washington, DC: American Association for Higher Education. 
Pager, Devah, 2002: The Mark of a Criminal Record. Ph.D. dissertation, Department of Sociology, University of Wisconsin, Madison, WI.

Park, Robert, 1972 [1904]: The Crowd and the Public. Chicago, IL: University of Chicago Press.

Parsons, Talcott, 1937: The Structure of Social Action. New York: McGraw Hill.

Parsons, Talcott, 1951: The Social System. New York: Free Press.

Parsons, Talcott, 1961: »An Outline of the Social System.«Pp. 30-79 in Theories of Society edited by Talcott Parsons/ Edward Shils/ Kaspar Naegele/ Jesse Pitts. New York: Free Press.

Patterson, Orlando, 2002: »The Last Sociologist.«The New York Times, May 19th.

President's Research Committee on Social Trends, 1933: Recent Social Trends in the United States. New York: McGraw-Hill.

Purser, Gretchen/ Any Schalet/ Ofer Sharone, 2004: Berkeley's Betrayal: Wages and Working Conditions at Cal. Presented at the annual meeting of the American Socioogical Association, August 16, San Francisco, CA.

Putnam, Robert, 2001: Bowling Alone: The Collapse and Revival of American Community. New York: Simon and Schuster.

Rhoades, Lawrence, 1981: A History of the American Sociological Association, 1905-1980. Washington, DC: American Sociological Association.

Riesman, David, 1950: The Lonely Crowd: A Study of the Changing American Character. New Haven, CT: Yale University Press.

Ryan, Charlotte, 2004: »Can We Be Compañeros.« Social Problems 51:110-13.

Schurman, Rachel/ William Munro, 2004: »Intellectuals, Ideology, and Social Networks: The Process of Grievance Construction in the Anti-Genetic Engineering Movement.« Department of Sociology, University of Illinois, Urbana-Champaign, IL. Unpublished manuscript.

Selznick, Philip, 2002: The Communitarian Persuasion. Baltimore, MD: Johns Hopkins University Press. Sen, Amartya, 1999: Development as Freedom. New York: Random House.

Sennett, Richard, 1977: The Fall of Public Man. New York: W.W. Norton.

Sitas, Ari, 1997: »The Waning of Sociology in South Africa.« Society in Transition 28:12-9.

Skocpol, Theda, 2003: Diminished Democracy: From Membership to Management in American Civic Life. Norman, OK: University of Oklahoma Press.

Smith, Dorothy, 1987: The Everyday World As Problematic. Boston, MA: Northeastern University Press.

Spalter-Roth, Roberta/ William Erskine, 2004: Academic Relations: The Use of Supplementary Faculty. Washington, DC: American Sociological Association.

Stacey, Judith, 2004: »Marital Suitors Court Social science Spin-Sters: The Unwittingly Conservative Effects of Public Sociology.« Social Problems 51:131-45.

Stacey, Judith/ Timothy Biblarz, 2001: »(How) Does the Sexual Orientation of Parents Matter?« American Sociological Review 66:159-83.

Stouffer, William et al., 1949: The American Soldier. Princeton, NJ: Princeton University Press.

Strand, Kerry, Sam Marullo, Nick Cutforth, Randy Stoecker,/ Patrick Donohue, 2003: Community-Based Research and Higher Education. San Francisco, CA: Jossey-Bass.

Turner, Stephen/ Jonathan Turner, 1990: The Impossible Science: An Institutional Analysis of American Sociology. London and Newbury Park, CA: Sage Publications.

Uggen, Christopher/ Jeffrey Manza, 2002: »Democratic Contraction? Political Consequences of Felon Disenfranchisement in the United States.«American Sociological Review 67:777-803.

Vaughan, Diane, 2004: »Public Sociologist by Accident.« Social Problems 51:115-18.

Waite, Linda/ Maggie Gallagher, 2000: The Case for Marriage. New York: Doubleday.

Wallerstein, Immanuel/ Calestous Juma/ Evelyn Fox Keller/ Jürgen Kocka/ Domenique Lecourt/ V.Y. Mudkimbe/ Kinhide Miushakoji/ Ilya Prigogine/ Peter J. Taylor/ Michel-Rolph Trouillot, 1996: Open the Social Sciences: Report of the Gulbenkian Commission on the Restructuring of the Social sciences. Stanford, CA: Stanford University Press. 
Wacquant, Loïc, 2004: »Following Bourdieu into the Field.«Ethnography 5(4).

Warner, Michael, 2002: Publics and Counterpublics. New York: Zone Books.

Webster, Edward, 2004: »Sociology in South Africa: Its Past, Present and Future.« Society in Transition $35: 27-41$.

Wilson, William Julius, 1996: When Work Disappears. New York: Knopf.

Wolfe, Alan, 1989: Whose Keeper? Berkeley, CA: University of California Press.

Michael Burawoy, Department of Sociology, University of California, Berkeley, CA 94720, USA. burawoy@berkeley.edu 